\title{
Experimental Unit Subgroup Code
}

National Cancer Institute

\section{Source}

National Cancer Institute. Experimental Unit Subgroup Code. NCI Thesaurus. Code C93837.

A coded value specifying the identification of uniform groups of subjects for separate analysis or treatment. 